\title{
The Utilization of Information Technology Media in Indonesian Language and Literature Learning
}

\author{
Mukti Widayati \\ Universitas Veteran Bangun Nusantara \\ Sukoharjo, Indonesia \\ mukti.widayati@yahoo.co.id
}

\begin{abstract}
The development of information technology becomes very important for the development of science. The progress contributes to the delivery of this knowledge to consumers who in this case are the students. Thus, the development of information technology can provide a very significant contribution to learning. Language and literature as a science cannot be separated from the influence of the development of information technology. Information technology can be used as a learning media to transfer all knowledge related to it. The problem is not only the readiness of students and teachers in operationalising the media but also facilities and infrastructure. This article is expected to contribute to the constraints of using information technology media in learning language and literature.
\end{abstract}

Keywords-constraints, information technology, and solutions.

\section{INTRODUCTION}

The internet as one of the technological developments in the world has a very important function and role in the development of science and communication. The internet can be used as a learning resource for teachers and students [6] because the internet is a vast source of information. Various subjects in school can be searched for learning resources that are integrated with subjects as teaching materials for students. Likewise, language and literary learning materials can be extracted from these sources.

The development of electronic media is a consideration of literary development. Literature as a medium of expression and communication is in tension with convention and innovation. The development of electronic media is increasingly becoming an option that allows readers to gradually leave newspapers, books, magazines, or print media, which have been the media for the expression of the authors. This is what became the anxiety that finally emerged the term cyber literature.

Based the opinion of [2], cyber literature is a literary activity that uses internet media. Not only writing literary works but also writing on literary criticism. Cyber literature has emerged along with the development of electronic media due to the demands of the times. The same thing and this time is being encouraged is literacy. Readers are required to be able to understand information from electronic media. In the field of literature, readers are required to be able to understand the meaning of literary works through electronic media, especially the internet.
In harmony with the literacy movement, readers are expected to explore literary elements and values contained in them. The results of this appreciation can be applied and implemented in education and in real life. Apart from that, the development of cyber literature in Indonesia seems increasingly rapid, stable and steady [11]. This proves that internet media is an effective and efficient media to express all thoughts, experiences, and views of life in the packaging of imagination and the creation of the author.

The presence of cyber literature cannot be underestimated. Along with its development, cyber literature has consumers or readers in special circles. Readers and writers who are in the struggle for time and activity choose in practical and effective ways. Therefore, the existence of cyber literature needs to be considered also in its contribution to education, especially in literary learning in schools. The opinion of literary experts who say literature is a mirror of society shows that literature is also related to the world of education. Students and teachers can jointly search for literary works as learning material by downloading from the internet. The material chosen is not separated from the syllabus as a basis for learning both learning outcomes and learning objectives. As said by [14], literary learning, especially novels, is seen as having relevance to social reality problems. This is very important, that literary studies can take an important role in the development of school education.

Cyber literature basically has the same characteristics as imaginative artwork. The facts of the story are the inventions of the authors arranged in such a way to become an interesting discourse. Intrinsically, cyber literature has its building elements. In prose, these elements include themes, plot, character, setting, point of view, language and style of language. The purpose of literary learning, in the end is that students can interpret, appreciate, assess literary works.

It is known that in literary learning delivered integratively in Indonesian language lessons. The process of learning literature becomes very important in language learning. Such learning can succeed if the process is carried out properly so that student learning outcomes are effective and efficient. That is, the delivery of learning material in a relatively short time, but get maximum learning outcomes. In the learning process requires the activeness and independence of students to understand the material given by the teacher and the activeness of students to learn their own subject matter at home. Students must be more active to get a lot of information, so students can understand the material 
well because learning will be more successful if the students themselves do.

Student activities in the process of learning Indonesian language and literature are less than optimal, one of the causes is the use of learning media. The use of media by teachers is generally limited and still monotonous, for example, only using picture media. Students experience boredom, passivity, not interested in the material. As a result, the results of language learning are low. These problems need to be anticipated by using creative, innovative, interesting and fun media for students. For this reason the use of media is absolutely necessary so that the material can reach students effectively and efficiently.

\section{METHODS}

This research focused on descriptive qualitative research.

\section{DISCUSSION}

Based on the literature study, this research discussed : In this era of globalization and information, the development of learning media is also progressing. The use of Information Technology (IT) as a learning medium is already a demand. Although designing IT-based media requires special expertise, it does not mean that the media is avoided and abandoned. IT-based learning media can be in the form of internet, intranet, mobile phone, and CD Room (Flash Disk). The main components include Learning Management System (LMS), and Learning Content (LC) [4]. The use of information technology includes operations, namely the use of tools to process and transfer data from one device to another. Because of this, mastering information technology means the ability to understand and use tools in general [6].

Teacher competency in utilizing information technology media, [15] in his research explained that there are seven competencies that need to be possessed, namely: (1) Suitability of media displayed with learning objectives, (2) Accuracy of IT media used with learning material, (3) The media used is adapted to the psychological state of the child, (4) All media to be used are available and easily available, (5) Costs incurred in using the media are in accordance with the benefits generated, (6) Ability to use available ICT facilities as learning media (PPT, internet, LCD projector), and (7) The accuracy of the media design used such as color, sound, and images displayed clearly.

The use of electronic media as a learning medium has not been maximized by the teacher. Some of the causative factors are the teacher's skill in using the media is still lacking, the facilities provided by the school have not met, the internet network has not been smooth. On the basis of this explanation, it can be seen that the teacher in Indonesian language learning has difficulty in choosing the right media for each material. Information Technology Media is expected to be able to answer the challenges in Indonesian Language Learning.
In its planning, the use of IT media in learning uses the principle of paying attention to individual student differences, to encourage students to actively participate in students, develop literacy cultures that are sustainable and can provide feedback and linkages and integration, and apply information and communication technology. The teacher assumes that all students can receive learning by the methods planned by the teacher. Allocations that are often a common obstacle in the use of this media can be anticipated by providing additional outside of class hours which is to provide intensive tasks.

[9] stated that to choose learning media, teachers need to pay attention to the principle of ease and ability to use media. The principle of ease means that the media used is easy to make, easy to find, not expensive, and practically used by teachers, the principle of ability means that whatever type of media is determined, it can be used and presented by the teacher.

At the initial level, IT-based learning is described as a learning process that has integrated IT progress into the learning process. All learning content is in the form of digital, and must be submitted because it is included in the 2013 curriculum structure.

The implementation of learning is the implementation of the learning plan. The course of the scenario learning process by the teacher with an educative atmosphere so that students can learn enthusiastically, actively, creatively and optimize their abilities well. The role of the teacher is very important in mobilizing and motivating students to do learning activities, both in the classroom, laboratory, library, and other places that enable the implementation of learning activities. Teachers aren't only trying to attract students 'attention, but also increase their students' activities through methods that are appropriate to the material being studied.

The National Education System Law Number 20 of 2003 states that National Education functions to develop the ability and shape of dignified national character and civilization in order to educate the lives of the nation, aiming to develop the potential of students to become faithful and devoted to God Almighty, noble, knowledgeable, creative, independent, responsible [16]. The duties and responsibilities of the teacher in carrying out the mandate of the national education goals, a teacher is required to have competence, professionalism and creativity in the implementation of learning, including in terms of the use of technology for the benefit of learning.

Information technology in learning can be used as a whole by all teachers. The teacher's paradigm when utilizing information technology in learning is not limited to the use of power point presentations. The use of the internet to find additional information about the material needs to be delivered and become a new learning system strategy that reintegrates with the learning process, as well as social networking can also be used as a learning system.

Teacher professionalism can be said to still be a major obstacle that is enough to interfere with the use of 
information and communication technology in learning, in addition to other technical barriers such as electricity and internet connectivity issues and financing problems. The main supporting factors are the availability of various facilities and infrastructure based on information and communication technology that are so adequate to accommodate the use of information and communication technology in learning.

Teacher obstacles in utilizing IT in learning Indonesian language and literature, among others; (1) the number of IT media available in schools are still limited (2) teachers have not optimally operated the IT media available in schools, (3) there is still a lack of learning training using IT, and (4) power outages or changes (up and down the voltage).

Obstacles often occur in the world of education, such as learning models, approaches, learning media and assessment of students. So it can be concluded that the obstacle is a problem or a situation that becomes an obstacle to achieving the goals to be achieved and must have certain solutions that are in accordance with the obstacles they face. The teacher's obstacle in the use of media is the visual, audio, audiovisual media that use computers.

With regard to teacher professionalism, based on Government Regulation No.74 of 2008 concerning teachers, there are four competencies that must be mastered, namely pedagogic, personality, social, and professional [17]. Professional competence can be interpreted as the teacher's ability to master and utilize various resources to support learning, including the ability to master science and information and communication technology in accordance with the times. Information technology provides new opportunities that are so broad that the creativity of a teacher becomes very important in utilizing the various new opportunities provided by technology, without the creativity of any sophisticated technology teacher will not provide optimal impact.

Forms of effort carried out by schools in order to optimize the use of IT by overcoming obstacles encountered. Based on the results of research in learning by utilizing IT media, there are four obstacles, namely: (1) the number of IT media available in schools is still limited (2) teachers have not been able to operate IT media available in schools, (3) there is still a lack of learning training with use IT, and (4) the electric current goes out or changes (the voltage drops).

\section{CONCLUSION}

This article provides a clear picture that the success of learning processes and outcomes is influenced by several factors, including teachers, students, methods, learning media and learning resources. The selection of methods and learning media that are less precise will affect the lack of interest and activeness of students in learning and low student learning outcomes. Therefore, in choosing learning media teachers should pay attention to its benefits for student development.

This article proves that through the use of Information Engineering media in student learning can be active, creative and conducive so that the goal of using information technology media in learning Indonesian language and literature can be achieved optimally. In learning can succeed one of them is influenced by the ability of the teacher in the use of information technology media. Therefore, teachers need to improve their knowledge and abilities in utilizing information technology media.

\section{ACKNOWLEDGMENT}

Thanks to the Directorate of Research and Community Service, Directorate General for Research and Development Reinforcement. Ministry of Research, Technology and Higher Education Subject to Contract Research Year 2018.

\section{REFERENCES}

[1] Bungin, Burhan. Analisis Data Penelitian Kualitatif. Jakarta: Raja Grafindo Persada. 2013

[2] Endraswara Suwardi. Metode Penelitian Sastra. Yogyakarta. Medpress. 2008.

[3] Moleong, L.J. Metode Penelitian Kualitatif. Bandung: PT Remaja Rosdakarya. 2012.

[4] Muhson, Ali. Pengembangan Media Pembelajaran Berbasis Teknologi Informasi. Jurnal Pendidikan Akuntansi Indonesia. 2017.

[5] Nugrahani, Farida. Metode Penelitian Kualitatif dalam Bidang Pendidikan Bahasa. Surakarta: Cakra Books. 2014.

[6] Rahim, Muhammad Yusuf. Pemanfaatan ICT sebagai Media Pembelajaran dan Informasi pada UIN Alauddin Makassar. Jurnal Sulesana Volume 6 Nomor 2 Tahun 2011.

[7] Sanjaya, Wina. Perencanaan dan Desain Sistem Pembelajaran. Jakarta: Kencana Prendamedia Group. 2014.

[8] Sudjana, Nana. Penilaian Hasil Proses Belajar Mengajar. Bandung : PT. Remaja Rosdakarya. 2011.

[9] Sudjana, Nana dan Ahmad Rivai. Media Pengajaran. Bandung: Sinar Baru Algesindo. 2011.

[10] Sugiyono. Memahami Penelitian Kualitatif. Bandung: Alfabeta. 2010.

[11] Supriatin, Yeni Mulyani. 2012. Kritik Sastra Cyber. Jurnal Sosioteknologi Edisi 25 Tahun 11, April 2012.

[12] Tarigan, Henry Guntur. Membaca Sebagai Suatu Ketrampilan Berbahasa. Bandung: Angkasa. 2012.

[13] Widayati, Sri. Sastra Cyber dan Sejarah Sastra Indonesia. (sriwidayati59.blogspot.com di 03.17), 2013.

[14] Yanti, Citra Salda. Religiousitas Islam dalam Novel Ratu yang Bersujud Karya Amrizal Maochamad Mahdavi.Jurnal Humanika No. 15, Vol. 3, Desember 2015/ISSN 1979-8296. 2011.

[15] Yusrizal, Intan Safiah, Nurhaidah. Kompetensi Guru Dalam Memanfaatkan Media Pembelajaran Berbasis Teknologi Informasi dan Komunikasi (TIK) di SD Negeri 16 Banda Aceh. Jurnal Ilmiah Pendidikan Guru Sekolah Dasar FKIP Unsyiah. 2017.

[16] http://pendis.kemenag.go.id/file/dokumen/uuno20th2003ttgsisdiknas. pdf

[17] http://simpuh.kemenag.go.id/regulasi/pp_74_08.pdf 